\title{
Correction to: Silenced IncRNA DDX11-AS1 or up-regulated microRNA-34a-3p inhibits malignant phenotypes of hepatocellular carcinoma cells via suppression of TRAF5
}

Gangqiang Ding ${ }^{*}$ (i), Yanli Zeng, Dongqiang Yang, Can Zhang, Chongshan Mao, Erhui Xiao, Yi Kang and Jia Shang

\section{Correction to: Cancer Cell Int (2021) 21:179}

https://doi.org/10.1186/s12935-021-01847-6

In this article [1], Supplement Figure 1 was misplaced. The correct supplement figure 1 is published in this correction (Additional file 1: Figure S1).

\section{Supplementary Information}

The online version contains supplementary material available at https://doi. org/10.1186/s12935-021-02360-6.

Additional file 1: Figure S1. The effect of DDX11-AS1/miR-34a-3p/TRAF5 on the malignant phenotype of xenografts. A-D. RT-qPCR detection of Ki67 and Caspase-3 mRNA levels in tumor tissues. The measurement data were expressed as mean \pm standard deviation. $t$ test was used for comparison between two groups, One-way ANOVA for comparison among multiple groups, and Tukey's post hoc test for pairwise comparison. $\wedge$ vs the sh-NC group, $P<0.05$; \# vs the mimic NC group, $P<0.05$; \# vs the pcDDX11-AS1 + mimic NC group, $P<0.05$; + vs the pcDDX11-AS1 + sh-NC group, $P<0.05$.

Accepted: 25 November 2021

Published online: 09 December 2021

\section{Reference}

1. Ding G, Zeng Y, Yang D, et al. Silenced IncRNA DDX11-AS1 or up-regulated microRNA-34a-3p inhibits malignant phenotypes of hepatocellular carcinoma cells via suppression of TRAF5. Cancer Cell Int. 2021;21:179. https://doi.org/10.1186/s12935-021-01847-6.

\section{Publisher's Note}

Springer Nature remains neutral with regard to jurisdictional claims in published maps and institutional affiliations. to the material. If material is not included in the article's Creative Commons licence and your intended use is not permitted by statutory regulation or exceeds the permitted use, you will need to obtain permission directly from the copyright holder. To view a copy of this licence, visit http://creativecommons.org/licenses/by/4.0/. The Creative Commons Public Domain Dedication waiver (http://creativeco mmons.org/publicdomain/zero/1.0/) applies to the data made available in this article, unless otherwise stated in a credit line to the data. 